\title{
1. The fundamental problem of regulating technology ${ }^{1}$
}

\author{
The Honourable Michael Kirby AC CMG²
}

\begin{abstract}
[T] he continued rapid advance in science is going to make life difficult for judges. We live in an age of breakneck technological change that will thrust many difficult technical and scientific issues on judges, for which very few of them (of us, I should say) are prepared because of the excessive rhetorical emphasis of legal education and the weak scientific background of most law students.
\end{abstract}

RA Posner, 'The role of the judge in the twenty-first century', Boston University Law Review, vol 86, 2006, p 1049.

\section{Present at the creation}

Preposterous claims: Dean Acheson, one-time Secretary of State of the United States of America, called his memoirs Present at the Creation (1969). It was a clever title, laying claim to having been at the important meetings during and after the Second World War in which the new world order was established.

The claim was faintly preposterous, given that the Second World War grew out of the first, and bore remarkable parallels to other conflicts dating back to the Peloponnesian Wars in ancient times. All history, and all technology, grow out of the giant strides that preceded their current manifestations. We forgive Acheson because (unlike some of his predecessors and successors) he was an elegant and sophisticated man, significantly concerned about improving the condition of the world and the welfare of its inhabitants.

I make an equally preposterous claim that I was present at the creation of the central problem that occasioned the TELOS ${ }^{3}$ conference to discuss the challenge

\footnotetext{
1 This chapter is based on the author's report on the TELOS conference, 8 April, 2007, London. The report was delivered orally at the close of the conference. Originally published in R Brownsword \& K Yeung (eds), Regulating technologies: legal futures, regulatory frames and technological fixes. This text has been revised and updated.

2 Justice of the High Court of Australia (1996-2009). One-time chairman of the Expert Group of the OECD on Transborder Data Flows and the Protection of Privacy (1978-1980). Formerly a member of the World Health Organisation Global Commission on AIDS and of the UNESCO International Bioethics Committee. 3 TELOS - Centre for the Study of Technology, Ethics and Law in Society, King's College School of Law, London.
} 
presented to legal regulation by the advent of modern biotechnology and information technology. The claim is absurd because such technologies have advanced by reason of the genius of technologists and scientists, who stand on the shoulders of their predecessors, also dating back to ancient times. ${ }^{4}$

In one of the closing talks at the conference, Professor Mireille Hildebrandt described the advances that had occurred in the communication of ideas in medieval times following the perfection of spectacle glasses and the invention of the printing press. The former allowed the monks, who spent their years inscribing religious texts, to extend their working lives beyond presbyopia. Yet it was the printing press that released words (and hence the ideas represented by words) from the calligraphy of the monks. For holy men, the words were written to be said or sung. But after Caxton, printed words took on a life of their own. Their meaning could be gathered without mouthing the sounds they conjured up. In a forerunner to the urgencies of the present day email and social networks, words could be read four times more quickly than they could be said. A revolution in communications had begun. It continues into our own times.

Acknowledging the lineage of contemporary technologies, the changes upon which the TELOS conference concentrated were information technology and biotechnology. They are major features of the contemporary world. From the perspective of the law, they present a common difficulty that, no sooner is a conventional law made to address some of their features, and to regulate those deemed necessary for regulation by reference to community standards, but the technology itself has changed. The law in the books is then danger of being irrelevant, in whole or part. Language written down at one time may have little, or no, relevance to events that happen soon thereafter.

Regulating biotechnology: This is the sense in which I claim to have been present at the creation of the two nominated technologies. It came about in this way.

In 1975, soon after I was first appointed to federal judicial office in Australia, I was seconded to chair the Australian Law Reform Commission (ALRC). The commission, a federal statutory body, was created after the model of Lord Scarman's Law Commissions in the United Kingdom (Kirby, 2006: 449; Murphy, 2009). Our task was to advise the Australian Parliament on the reform, modernisation and simplification of Australian federal law.

One of the first inquiries assigned to the ALRC concerned an issue of biotechnology. The Attorney-General required us to prepare a law for the Australian Capital Territory (ACT) (a federal responsibility) to deal with the

4 Sir Isaac Newton in a letter to Robert Hooke, 5 February 1675/6 wrote: 'If I have seen further it is by standing on the shoulders of giants'. 
issues presented to the law by human tissue transplantation (ALRC, 1977). The project was initiated in July 1976. The commission was obliged to report no later than 30 June 1977. The timetable was very tight.

In the event, the commission fulfilled its mandate. It produced its report on time. Within Australia, the report proved highly successful. Not only did it result in the adoption of a law on this aspect of biotechnology for the ACT; ${ }^{5}$ the draft legislation attached to the ALRC's report was soon copied in all parts of Australia. ${ }^{6}$ Such was the universality of the issues that we addressed that the report was also quickly translated into languages other than English and used overseas in the development of the laws of other countries.

The report described the then rapid advances that had occurred in transplantation surgery. The earliest attempts in this technology were dated back 2000 years. Instances of the transplantation of teeth in England at the close of the eighteenth century, of successful bone transplantation at the close of the nineteenth century and of transplantation of organs such as the kidney dating from the early 1950s (Woodruff, 1968: 380, 521-25), indicated that this was an area of human activity that probably required fresh legal thinking. One of the events that had propelled the Federal Attorney-General in Australia into action on this subject was the worldwide controversy that had surrounded the first transplantation of a human heart in South Africa in December 1967 by Dr Christiaan Barnard. The recipient died 18 days later from pneumonia. But successful long-lasting operations quickly followed.

The ALRC was quite pleased with itself for getting its report completed on time. After all, there were many difficult and controversial legal topics of regulation to be addressed. These included:

- whether a system of 'opting in' or 'opting out' should be accepted to permit the

- removal of human tissue from the source

- whether legal minors should be permitted to give consent, as for a sibling recipient

- and, if so, under what conditions

- whether payments for human organs should be forbidden in all circumstances

- whether organs might be taken from prisoners and other dependent persons for transplantation

- whether tissue might be removed from coroner's cadavers

5 Transplantation and Anatomy Act 1978 (ACT).

6 Human Tissue Transplant Act 1979 (NT); Transplantation and Anatomy Act 1979 (Qld); Human Tissue Act 1982 (Vic); Human Tissue and Transplant Act 1982 (WA); Human Tissue Act 1983 (NSW); Transplantation and Anatomy Act 1983 (SA); Human Tissue Act 1985 (Tas). 
- whether blood was to be treated separately or as just another human tissue

- how 'death' should be defined for legal purposes, as a precondition to the removal of vital organs for transplantation.

As the ALRC was producing its report, it became aware of a 'major medical development ... expected within the near future - possibly the next two or three years'. This was described as 'the fertilisation of human egg cells outside the human body'. The process of in vitro fertilisation (IVF) and embryo transplantation was therefore mentioned in the report. However, the ALRC recognised that the fertilisation of the ovum of a woman by the use of donor semen, whether in utero or in vitro, raised issues different in kind from those presented by the transplantation of particular organs and tissues. Whether or not embryo transplantation literally fell within its terms of reference, the ALRC felt bound to exclude the subject from its report and proposed legislation. If there were to be an inquiry into IVF, it would require a separate reference (ALRC, 1977: 18-19 [41]-[42]).

Similarly, the ALRC had become aware, even at that time 30 years ago, of the potential of transplantation of foetal tissue. It noted that work on foetal tissue transplants 'may have already begun in Australia' (ALRC, 1977: 20 [45]-[46]). Already 'right to life' organisations and others had made submissions calling for legal prohibitions. Reports in Britain (Peel, 1972), the United States (National Commission for the Protection of Human Subjects of Biomedical and Behavioural Research, 1975), and New Zealand (Royal Commission on Contraception, Sterilisation and Abortion, 1977), were mentioned. Once again the subject was sidestepped.

The ALRC inquiry afforded a vivid illustration of how, in the regulation of technology, events rarely, if ever, stand still. Even between the time that the ALRC initiated its project on human tissue transplantation law and the time it reported, the technology had marched on. Draft legislation prepared to address other topics was unsuitable, and plainly so, for the more sensitive and complicated issues emerging from IVF and foetal tissue transplants. Before long, Louise Brown was born in England. Eventually, special laws on IVF were adopted in Australia, as elsewhere. ${ }^{7}$ As I was to learn in my judicial capacity, such laws and the issues involving the availability of IVF for unmarried or same-sex recipients, invoke strong feelings, conflicting demands and different regulatory responses in different places. $^{8}$

Regulating information technology: Soon after the completion of the law reform project on human tissue transplants, the ALRC was asked to prepare

7 See, for example, Infertility Treatment Act 1995 (Vic); Reproductive Technology (Clinical Practices) Act 1988 (SA); Human Reproductive Technology Act 1991 (WA).

8 Re McCain; Ex parte Australian Catholic Bishops Conference (2002) 209 CLR 372. 
recommendations on reform of the Australian law governing the protection of privacy. This too led to a major inquiry although, in this case, the object was the preparation of proposals for federal legislation, suitable for enactment by the Australian Parliament. In the result, a number of reports were delivered on the topic. ${ }^{9}$ The major report, delivered in 1983, dealt with many aspects of privacy protection under federal law.

As befitted its delivery on the brink of 1984, a major focus of the 1983 report was the new information technology. Even at that time, that technology had significantly changed the way in which information was collected and distributed and the amount of personal information that could be communicated.

Because of the currency of the Australian inquiry, I was sent as the Australian representative to a group of experts convened by the Organisation for Economic Cooperation and Development (OECD) in Paris. That expert group was formed to make recommendations to member countries of the OECD on guidelines for the protection of privacy in the context of trans-border data flows. In the event, I was elected to chair the OECD expert group. It conducted its inquiry between 1978 and 1980, drawing upon principles already developed in relation to automated and non-automated data systems by the Nordic Council, the Council of Europe and the then European Economic Community. In the result, guidelines were agreed to by the OECD (1980). They were to prove influential in the development of the national laws of member states, influencing the design and contents of such laws in countries with legal systems as diverse as Australia, Canada, Japan and the Netherlands and corporate practice in the United States. The Australian Privacy Act, based on the ALRC report, was enacted by the Australian Parliament in $1988 .^{10}$

Annexed to the Australian Privacy Act, in Schedule 3, were 'national privacy principles'. As the Act declared in its Preamble, its purpose included compliance by Australia, as a member of the OECD, with the recommendation of the Council 'that member countries take into account in their domestic legislation the principles concerning the protection of privacy and individual liberties set forth in Guidelines annexed to the recommendations'. The Act recited that Australia had 'informed that organisation that it will participate in the recommendation concerning those Guidelines' ${ }^{11}$ Hence, the national privacy principles adopted by the new federal law.

A difficulty soon became apparent. It did not arise out of any defect in the understanding of the OECD expert group, or of the ALRC in its recommendations to the Australian Government and Parliament, concerning the technology

9 See, ALRC 1979(a), 1979(b), 1983.

10 Privacy Act 1988 (Cth).

11 Privacy Act 1988 (Cth), Preambles 4 and 5. 
Professionalism in the Information and Communication Technology Industry

then deployed. That technology, however, quickly changed in its potential. Moreover, it did so in a way that rendered an assumption, expressed in the OECD guidelines and the Australian national privacy principles, out of date (at best) and irrelevant (at worst).

Illustrating the issue by reference to the 'use and disclosure' principle, the second in the Australian national privacy principles, this principle stated:

2.1 An organisation must not use or disclose personal information about an individual for a purpose (the secondary purpose) other than the primary purpose of collection unless:

(a) Both of the following apply:

(ii) The secondary purpose is related to the primary purpose of collection and, if the personal information is sensitive information, directly related to the primary purpose of collection;

(ii) The individual would reasonably expect the organisation to use or disclose the information for the secondary purpose; or

(b) The individual has consented to the use or disclosure; or

(c) If the information is not sensitive information and the use of the information is for the secondary purpose of direct marketing [certain provisions follow]; or

(e) The organisation reasonably believes that the use or disclosure is necessary to lessen or prevent:

(i) A serious or imminent threat to an individual's life, health or safety; or

(ii) A serious threat to public health or public safety; or

(f) The organisation has reason to suspect that unlawful activity has been, is being or may be engaged in ...; or

(g) The use or disclosure is required or authorised by or under law; or

(h) The organisation reasonably believes that the use or disclosure is reasonably or necessary for one or more of the following by or on behalf of an enforcement body.

[Provisions on law enforcement follow].

The basic hypothesis of the OECD guidelines (and therefore of the ALRC recommendations) and the Privacy Act was that personal information that was 
collected should ordinarily be used for the purpose for which it was collected and that such purpose should be made known to the individual at the time of the collection. ${ }^{12}$ Then, along come search engines, including Google and Yahoo. The specification of purposes of collection and the limitation of use and disclosure by reference to such purposes went out the window. ${ }^{13}$

This is the sense in which I assert that I was present at the creation of the problems addressed in the TELOS conference on the regulation of new technologies. Accepting as paradigm instances the cases of biotechnology and information technology that I have described, the difficulty (in some cases near impossibility) was soon apparent in drafting any law of the conventional kind that would not quickly be overtaken by events. In part, legal texts might be overtaken by advances in technology of the kind that I have described. But, in part too, changes in social attitudes, themselves stimulated by advances in technology and a perception of the utility of the advances, made it more difficult than in other fields of law to draw a clear line in the sand.

The caravan of controversy: Take for example, in vitro fertilisation. In 1976, when the ALRC report Human tissue transplants was written, many earnest debates were conducted over the suggested ethical quandary of transplantation of ova fertilised by a husband's sperm. These debates were quickly replaced by new ones concerned with the use of non-husband (donor) sperm. Such debates are now rarely raised, even in esoteric legal circles. Today the ethical (and legal) debates in Australia and elsewhere are more likely to be concerned with the availability of IVF to single parents and to same-sex couples. Thus, the caravan of controversy moves on. A law drafted too early may freeze in time the resolution of earlier controversies, which may later be regarded as immaterial or insignificant.

Napoleon reportedly observed a principle of never responding to letters for at least a year. He adopted this principle on the footing that, if the problem still existed a year later, it would be time enough for it to receive the Emperor's attention. Whether by default, or by design, many issues presented to the law by contemporary technology appear to receive the same treatment. One suspects that, in many instances, it is because of the complexity and sensitivity of the issues rather than a strategic policy of lawmakers to postpone lawmaking or clarification of regulation until the contours of the necessary law have become clear.

\footnotetext{
12 Privacy Act 1988 (Cth), Schedule 3: 'Privacy Principle 1 (Collection:)'.

13 Another illustration arises out of the enactment of provisions requiring that confessions and admissions to police, by suspects in custody, should be recorded on 'videotape'. See, for example, Criminal Code (WA), s $570 D(2)(a)$. The change to digital technology necessitated amendment of such laws to substitute a requirement for 'audio-visual recording'. See Criminal Investigation Act 2006 (WA), s 118(1).
} 


\section{Five paradoxes}

1. Doing the best without experts: Having laid the ground for my competence to provide a summation of the London TELOS conference, I will start by identifying a number of paradoxes, or at least curiosities, that emerged during the debates. The first of these curiosities is a reflection not only on my own limited competence but also on the limited competence of everyone else.

There are no real experts on the subject of regulating technologies. They do not exist in the United Kingdom, the United States, Australia or elsewhere. It is much easier to find an expert on the intellectual property implications of biotechnology and information technology than it is to find someone skilled in considering what new law, if any, should be adopted to deal with a particular issue presented by technology and how it should be devised. Easier by far to find an expert on income tax or unjust enrichment or international human rights law than to find scholars, judges or even legislative drafters who can claim to be experts in the interface of law and technology.

It is true that we had the privilege at TELOS of an opening address by Professor Lawrence Lessig, then professor of law at Stanford Law School in the United States. He was founder of that school's Center for Internet and Society. Lessig's book Code and other laws of cyberspace (now updated by Code V2) blazed a trail. He launched the host organisation, TELOS. On the interface of cyberspace and the law, he is something of a guru. His launching speech, like his books, challenged us all to think afresh. His novel thesis is that 'Code', or the architecture of technological systems, will sometimes incorporate regulatory imperatives into information technology, obviating any real choice on the part of the user as to whether or not to conform to the law.

In the High Court of Australia we came face to face with this reality in Stevens $v$ Kabushiki Kaisha Sony Computer Entertainment. ${ }^{14}$ The case concerned a claim by Sony Corporation of breach of a 'technological protection measure' installed by it in the program of its computer games. Sony asserted that the measure was protected under the Australian Copyright Act 1968. Sony argued that Stevens had unlawfully sought to circumvent the device incorporated in computer games that it produced and sold on CD-ROM for use in its PlayStation consoles.

14 (2005) 224 CLR 193; [2005] HCA 58. 
Applying a strict interpretation to the expression 'technological protection measure', the court held that Sony's device did not fall within the statute. I agreed in this analysis. ${ }^{15}$ The case was a vivid illustration of the way in which, for copyright, contractual and other legal purposes, attempts are now often made to incorporate regulatory provisions in the relevant technological codes. It is a new development, although I suppose one might see primitive attempts directed at the same object in the safety provisions incorporated in the design of houses, bridges and aeroplanes. The computer PlayStations simply take this development to a higher level of sophistication and technological capability. Lessig identified this new development. Inevitably, his expertise did not include all of the current major technologies, still less the way in which law can regulate them.

I, too, am no expert in the design of laws. True, in the High Court of Australia, I participated in a final national court that sometimes declares new laws. I worked for a decade in national law reform, as I have described. True, also, I have participated in the drafting of international guidelines, such as those of the OECD. ${ }^{16}$ This, however, is hardly an intensive preparation for the complex and highly technical task of drafting laws for, or under, a legislature. I have become rusty since, in my law reform days, I worked with former parliamentary counsel on the draft legislation annexed to the ALRC's reports.

Nor can it be said that the academics present at the conference had any special skills (at least skills that any of them revealed) in drafting statutes and subordinate regulations. Professor Brownsword confessed to beginning his academic career by teaching contract law, with later experience in consumer and environmental law. Whilst the latter fields are overburdened with a mass of regulation, it is different to use and interpret such laws, on the one hand, and on the other to design and draft them. Many participants in the conference were, to use the words of Judy Illes, trained as 'bench scientists'. Although the experience of authentic scientists and technologists was essential to an understanding of the problem, it did not necessarily provide the best guidance for legal solutions.

VI Lenin once declared that the person who writes the minutes of an organisation usually ends up controlling it. His work as general secretary of the Soviet Communist Party obliges us to take this advice seriously.

15 (2005) 224 CLR 193 at 246 [186].

16 Also as chair of the UNESCO International Bioethics Committee drafting group for the Universal declaration on bioethics and human rights, adopted by the General Conference of UNESCO, Paris, October 2005. See Andorno, 2007: 150. 
We may complain about the absence of law concerned with new and cutting-edge technology. We may acknowledge our own imperfections for addressing the gap. We may recognise, with Lessig, that regulation in the future may not necessarily come in the form of written instruments made by or under the legislature and published in the Government Gazette.

Nevertheless, the issue tackled in the TELOS conference was undoubtedly one of the greatest importance for the future of the rule of law in every society. Despite the manifold interpretations of those whom it invited to its conference, TELOS may, in the long run, have a paradoxically disproportionate impact on perceptions of how technologies may be regulated and used in regulation, simply because it is one of the first organisations to tackle this issue generically. It surveys what is substantially a blank page. Increasingly the content of law, like the content of life, will be concerned with technology and with its many consequences for society. The importance of the chosen topic, therefore, belies the comparatively little that is written, said and thought about it. Paradoxically, then, those who first lay claim to expertise may participate in a self-fulfilling prophesy.

2. Too much/too little law: The second paradox is that most of us recognise that the failure to provide law to deal with the impact of particular technologies is not socially neutral. Effectively, to do nothing is often to make a decision.

Thus, for the law to say nothing about reproductive cloning of human beings, for example, (assuming that outcome to be technically possible) is to give a green light to experiments in that technology. In so far as the law expresses prohibitions supported by sanctions that uphold the command of a sovereign power, silence may, for once, imply consent or at least non-prohibition. Thus, if there is no law to prohibit or regulate reproductive cloning or hybridisation or xeno-transplants, scientists and technologists at their benches may decide to experiment. Nothing then exists to restrain them except their own ethical principles, any institutional ethics requirements, the availability of funding and the prospects of a market. A scientist or technologist may proceed out of sheer curiosity, as when David Baltimore so beneficially investigated a simian retrovirus a decade before the discovery of the immunodeficiency virus in human beings.

The scientist or technologist may, of course, do this in the hope of cashing in on a potentially lucrative therapeutic market. One such market certainly exists in respect of therapies to overcome human 
infertility. Reproductive human cloning might, potentially, be one such therapy. Some of its supporters treat with contempt the supposed moral objections to this form of scientific advance (Robertson, 2001: 35; Shikai, 2002: 259). They point to earlier resistance to other reproductive technologies such as artificial insemination donor (AID), artificial insemination husband (AIH), IVF and surrogacy arrangements. ${ }^{17}$ Most of these objections have faded away as society becomes more used to 'nonnatural' ways of securing a desired pregnancy in a particular patient.

The recognition that inaction in the face of significant technologies may amount to making a decision coexists with our appreciation, as observers of the law, that premature, over-reaching or excessive lawmaking may, in some cases, be an option worse than doing nothing. It may place a needless restriction upon local scientists and technologists, obliging them to take their laboratories and experiments offshore.

In a big world with diverse cultures, religions and moral beliefs, it is never difficult to find a place offering a regulation-free zone in exchange for investment dollars. Just as bad is the possibility that laws are solemnly made and then ignored or found to be ineffective, as was temporarily the case with the 'technological protection measure' considered in the Australian Sony litigation. Following the decision of the High Court of Australia in that case, and under pressure from the US government under the United States-Australia Free Trade Agreement, Australian law was changed. The new law represented an attempt to overcome the High Court's decision in the Sony Case, although in a somewhat different way. ${ }^{18}$

Many participants in the TELOS conference, whether expert in matters of biotechnology or information technology, revealed themselves as legal libertarians. They were so mainly because of their recognition of the common potential of premature, over-reaching and ill-targeted laws to diminish experimentation, burden innovation and cause economic and other inefficiencies. Thus, Han Somsen presented a number of compelling arguments about the dangers of the 'precautionary principle' (Andorno, 2004). Whilst this principle appears to be gaining increasing

\footnotetext{
17 The New South Wales Law Reform Commission in 1988 recommended a prohibition on surrogacy arrangements that was not implemented. Surrogacy arrangements are, however, regulated in some Australian jurisdictions: Parentage Act 2004 (ACT); Surrogate Parenthood Act 1988 (Qld); Family Relationships Act 1975 (SA); Surrogacy Contracts Act 1993 (Tas); and Infertility Treatment Act 1995 (Vic).

18 For the story of the change of law following the decision in the Sony case, see de Zwart (2007: 7); in contrast, see D Brennan, 'What can it mean "to prevent or inhibit the infringement of copyright"? : - a critique of Stevens $v$ Sony', Australian Intellectual Property Journal, vol 17, 2006, p 86. See also Copyright Amendment Act 2006 (Cth) implementing the new scheme said to be required by art 17.4.7 of the AustraliaUnited States Free Trade Agreement.
} 
acceptance in the international community, particularly in respect of protection of the global environment, it carries risks of its own. If taken too far, it could instil a negative attitude towards science and technology and encourage excessive regulation in the attempt to avoid any risks. Life is risky. Most technological innovations carry some risk. An undue emphasis on precaution, for fear of any risks, would not be good for science or technology or for the global economy or for innovation in thought as well as action.

The second paradox is thus more of a contradiction or tension, and difficult to resolve. At the one time we must accept that doing nothing to regulate technologies involves making a decision. Yet we must also recognise that sometimes doing nothing will be a better option than making laws that impede innovation and burden efficiency.

3. First Amendment and copyright law: An early illustration of the second paradox arose in Lessig's opening address, which was concerned with the potential of 'Code' (or information technology architecture) to play a part in regulating technology in ways more universal and immediately effective than most laws are.

An instance, frequently mentioned, is the installation of filters designed to prohibit access to materials considered 'harmful to minors'. Many countries now have legal regulations forbidding access to, or possession of, child pornography. Available software may prevent access to sites providing such images. But sometimes they may do so at a cost of overreaching prohibitions. The burden on free communication may outstrip the legitimate place of legal regulation, forbidding access not only to child pornography but to lawful erotic materials or discussion about censorship itself or to websites concerned with subjects of legitimate interest, such as aspects of human sexuality, women's rights and even children's rights.

Whereas the law will commonly afford avenues of appeal and review of decisions that purport to apply legal norms, an over-reaching 'protective' software program may afford no such rights of challenge. Those concerned with the human right of free expression are naturally anxious about the potential of 'Code' to re-institute excessive censorship in society, just when we thought we had grown out of that habit.

Like most American lawyers, Lessig approached these issues from the standpoint of the First Amendment to the US Constitution. ${ }^{19}$ This

19 Relevantly, the First Amendment states: 'Congress shall make no law ... abridging the freedom of speech, or of the press'. 
upholds a very high level of unrestricted and unregulated freedom of communication. The rest of the world tends to be less absolutist in this respect. ${ }^{20}$ It recognises that, whilst 'free' expression and access to a 'free' media constitute important human rights, they are not unlimited. They have to be harmonised with other fundamental human rights. These include the right to individual honour and reputation and to protection of privacy and family relationships. ${ }^{21}$ They also include protection of the legitimate rights of inventors. ${ }^{22}$

Lessig expressed concern about the balance that has been struck in the United States between rights to free expression and the right to copyright protection that impinges on free expression. ${ }^{23}$

In an international meeting such as the TELOS conference, we were not, as such, concerned with the particularities of US law, including the way the constitutional law of that country reconciles free expression and lawful copyright protection. On the other hand, because of the dominance of the US media and its hegemony in entertainment and popular culture, what is done in that country to regulate information technology obviously has consequences worldwide. Just as, in earlier decades, the hard copy issues of Playboy, circulating in huge numbers around the world, broke down the prevailing culture of censorship, carrying First Amendment values virtually everywhere, so today the inbuilt 'Code' or architecture of information systems may carry US legal protections for US copyright holders far beyond the protections that the laws of other countries afford them. ${ }^{24}$

This consequence can present legal and practical problems for the regulation of technology in jurisdictions enjoying different capacities to contest the balances struck by the Constitution and laws of the United States. In smaller economies, there may be no real choice. Upholding the local constitution and its values may, as a matter of practicalities, be impossible. Consumers may be presented with no real option. If they buy the software that drives the PlayStation, they may find that it reflects US

\footnotetext{
20 For example, ABC v Lenah Game Meats Ltd (2001) 208 CLR 199 at 283 [202] ([2001] HCA 63); Dow Jones and Co Inc v Gutnick (2002) 210 CLR 575 at 626 [115] ([2002] HCA 56).

21 International Covenant on Civil and Political Rights (1976) arts 17.1, 17.2 and 19.3.

22 cf Universal Declaration of Human Rights (1948) art 27.1; International Covenant on Economic, Social and Cultural Rights (1976), art 15.1(b) and (c).

23 Cf Nintendo Co Ltd $v$ Sentronics Systems Pty Ltd (1994) 181 CLR 134 at 160; Grain Pool of WA $v$ The Commonwealth (2000) 202 CLR 479 at 531 [133], fn 266 ([2000] HCA 14) referring to Graham v John Deere \& Co 383 US 1 at 6 (1966); Feist Publications Inc v Rural Telephone Service Co Inc 499 US 340 at 348 (1991) and L Lessig, Code and other laws of cyberspace (1999), pp 131, 133-34.

24 Stevens $v$ Kabushiki Kaisha Sony Computer Entertainment (2005) 224 CLR 193 at 256 [216] citing L Lessig, Code and other laws of cyberspace (1999); see Fitzgerald, 2005: 96. See also Metro-Goldwyn-Mayer Studios Inc v Grokster Ltd 73 USLW 4675 (2005).
} 
constitutional and copyright laws. Indeed, such software may exceed even the protections afforded by those laws. It is in this sense that 'Code' and architecture may challenge the previous assumption that, within its own borders, each nation state is entitled, and able, to enforce its own laws, reflecting its own values. In Australia, we gained a glimpse of things to come in the Sony litigation. But it was only the beginning.

The debate that Lessig recounted between First Amendment values and the current state of US copyright law presents a microcosm of similar conflicts in every society. There is an element of the paradoxical about it in the United States. This is because, as Lessig put it, intellectual property law in that country has been able, to some extent, to slip under the radar of First Amendment values. To a large extent, intellectual property law has developed separately and, in part, inconsistently. This point was noted by me in my reasons in Sony. Eventually, in the United States, Britain, Australia and elsewhere, it will be necessary to face directly the tension between enlarging copyright protection (including through the use of the technological architecture of information technology) and adhering to high levels of free communication, unimpeded by undue governmental regulation (such as by copyright law ${ }^{25}$ ).

The conflict recounted by Lessig presents a paradox, visible to nonAmericans and to American lawyers themselves. ${ }^{26}$ The country that has been foremost in promoting values of free expression and the free press has also lately been foremost in promoting, extending and enforcing the intellectual property rights of its own creators, 'inventors' and designers. This is not only true in the context of information technology. It is also true in the case of biotechnology, as the closely divided decision of the Supreme Court of the United States in Diamond $v$ Chakrabarti, ${ }^{27}$ and its progeny, demonstrate. Lessig appreciated, and highlighted, this paradox. It appears in an acute form in the United States. But it has its counterparts everywhere.

4. Technology's democratic deficit: A fourth paradox derives from the way in which contemporary technology at once enhances, and diminishes, democratic governance. No one at the TELOS conference questioned the importance of science and technology in the current age. Similarly, no one questioned the desirability of rendering laws, and regulation more generally, available and accountable to the people from whom authority 
to govern society is ultimately derived. On balance, however, does technology enhance or reduce democratic accountability for the state of the resulting regulations?

In some respects, there can be no doubt that technology has improved communication that is essential to converting the formalities of electoral democracy into the realities of genuine accountability of the governors to the governed. Radio, television, worldwide satellite communications, the internet, podcasts, blogs, Facebook, YouTube, and Twitter have revolutionised the distribution of information about those persons and institutions whose decisions affect the regulation of our daily lives. In this sense, democratic governance has moved from small, town hall assemblies of earlier times into huge, national and international forums both public and private.

Paradoxically the very quantity of information has resulted in its manipulation and presentation in a way that is often antithetical to real democratic accountability. The technology stimulates a demand for the simplification and visualisation of messages, the personalisation of issues, the trivialisation of conflict, the confusion between fact and opinion and the centralisation and 'management' of news. So-called 'spin' and 'infotainment' are characteristics of media in the present age. They tend to concentrate power in a way that even George Orwell could not have imagined.

Several speakers at the TELOS conference referred to yet another feature of contemporary technology that can be inimical to democracy. This is the incorporation of regulation in the technology itself that goes beyond what is strictly required by local law, yet without effective opportunities for those affected to challenge the regulation so imposed. Who can, or would, challenge the over-inclusive software designed to bar access to Internet sites selected as 'harmful to minors' but sometimes operating in an over-inclusive way?

When serving on the High Court of Australia, I found that the website of the Archbishop of Canterbury was barred to my use. My staff were unable to access one of the Archbishop's addresses. This was presumably because a filter, instituted to deny access to websites deemed undesirable, had erected a bar. Ostensibly, this was because, in the manner of these times, one or more of his Grace's addresses dealt with issues of sex, specifically homosexuality. In fact, that was exactly why I wanted the speech. I was surprised to find that, at the same time, the Vatican website was accessible without any restriction. This may say something either about the prudence of the then Pope's choice of language, the power of 
the Roman Catholic Church in such matters, or the religion of the filter programmer. I gave directions that led to the filter being over-ridden. I secured a copy of the desired speech. But many might not be so lucky.

Given the importance of technology to the current age, how do we render those who design, install and enforce such programs accountable to the democratic values of our society? As 'Code' enlarges and replaces the old-style legal regulation of technology, how do we render its architects answerable to the majority views of the people? How, if at all, are transnational corporations, like Sony for instance, rendered responsible to the democratic values of the nations in which their products are used?

These are legitimate questions because the fourth paradox is the coincidence, at the one time of history, of technologies that vastly enhance access to information that jumped the Berlin Wall, bringing messages of freedom, at the same time as they sometimes diminish genuine debate, enlarge unreviewable 'technological' corporate decisions and expand the capacity to 'manage' news in a way inimical to real transparency and accountability of decision-makers to the people.

5. Vital but neglected topics: I reach my fifth, and final, paradox. The TELOS conference addressed one of the most important issues for the future of the rule of law in every country. Because of the elusiveness of much contemporary technology to effective regulation, large and increasing areas of activity in society find themselves beyond the traditional reach of law as we have hitherto known it. When regulation is attempted, as I have shown, it will often be quickly rendered ineffective because the target has already shifted. Typically, in the past, the drawing up of laws has been a slow and painstaking process. Consulting governments and those primarily affected, not to say the people more generally, takes time. In that time, the technology may itself change, as I have demonstrated from my experience with human tissue transplantation and privacy laws. Now, new regulation are being developed in the form of what Lessig calls 'Code'. Yet, this form of regulation is not so readily susceptible, if susceptible at all, as conventional laws in the past have been, to democratic values and to the participation (or even appreciation) of most of those affected in the moral choices that determine the point at which the regulation is pitched.

If, on the same weekend in London, King's College School of Law had convened a conference on revenue law, it would have filled a convention hall. A month earlier, in Hobart, Tasmania, I addressed more than 600 lawyers and accountants at such a conference. Similarly, a conference on the law of unjust enrichment would attract hundreds of contributors, 
with their differing opinions. Even a meeting on the rule against perpetuities would probably have attracted more participants than the inaugural conference of TELOS. Yet, in truth, the issues addressed by TELOS were more important for our societies and their governance than virtually any of the other topics that the legal discipline could offer.

It sometimes falls to small groups, particularly in professions, to lead the way and to bring enlightenment to the many. This, then, is the fifth paradox - at least it is an oddity. Such an important topic as the regulation of burgeoning technologies in modern society should engage the interest and attention of all who claim to be lawyers, sociologists and philosophers and express an interest in the health of the rule of law. Yet, for the moment, and for most such observers, this is terra incognita. The contributions at the TELOS conference suggest that it will, and should, not be so for long.

\section{Seven lessons}

1. Recognise a basic dilemma: Certain general lessons therefore stand out from the presentations at the TELOS conference. Some of them have already been touched on.

The first is that, the regulation of technology faces a fundamental dilemma hitherto relatively uncommon in the law. This is that, of its character, technology is normally global. Law, being the command of an organised community, is traditionally tied to a particular geographical jurisdiction. Whereas in recent years the need for extraterritorial operation of municipal law has been recognised, and upheld ${ }^{28}$ the fact remains that the focus of most national law is the territory of the nation. By way of contrast, the focus of regulating technology must be the technology itself. ${ }^{29}$ Sometimes, that feature of the technology will make effective regulation by national law difficult, or even impossible.

It is into this context that direct enforcement by 'Code', written into software programs or otherwise imposed, adds a new dimension to global technology. The values and objectives of transnational corporations may be even more unresponsive to national regulation than the rules of a municipal legal system are. Moreover, 'Code' of this kind may opt for caution and over-inclusion so as to avoid dangers to markets in the

28 Re Aird; Ex parte Alpert (2004) 220 CLR 308 at 344-350 [114]-[133]; ([2004] HCA 44) referring to the case of the SS Lotus (1927) Permanent Court of International Justice, Series A, No 10, Judgment No 9, pp 18-19 and Martinez (2003: 429).

29 Dow Jones (2002) 210 CLR 575 at 615-619 [78]-[92]. 
least right-respecting countries. The contractual arrangements entered between the government of the People's Republic of China and the corporations selling access to Yahoo and Google in China, which were described during the conference, illustrate the willingness of the latter to succumb to the demands of the former so as to avoid endangering a lucrative economic market for their products. In this way the provider, but also the users, are subjected to forms of censorship that might not be tolerated in other societies. A smaller country, with a smaller market, is unlikely to exert the same clout. Considerations of economics rather than of legal principle, ethical rules or democratic values may come to predominate in such cases.

2. Recognise that inaction is a decision: In the past, proponents of technological innovation have often favoured containment of law and a 'libertarian' approach to developments of technology. Yet, most lawyers recognise that there are limits. Unless such limits are clearly expressed, and upheld in an effective way, the absence of regulation will mean, effectively, that the society in question has made a decision to permit the technological advances to occur, without impediment.

Those who are cautious about adopting any form of the precautionary principle may yet recognise the need for some restraints. Thus, unlimited access to child pornography will probably offend most people and sustain a call for regulation of the Internet to prohibit or restrict access to such sites. However, that will still leave room for debate about the detailed content of such regulation: the age of the subjects depicted; any permissible (computer graphic or cartoon format rather than human) images; the means of enforcing the law; and the provision of effective sanctions. ${ }^{30}$ Cases on these issues, and on any constitutional questions that they present, are now quite common. ${ }^{31}$

Likewise with biotechnology. Views may differ over whether regulation is necessary, or even desirable, to prohibit therapeutic cloning, reproductive cloning or the use of human embryonic stem cells. Yet, non-binding prohibitory resolutions and declarations have been adopted in the organs of the United Nations on this subject. ${ }^{32}$ Even those nations, like the United Kingdom, that have not favoured prohibitions or moratoriums on experiments with human cloning for therapeutic

30 Bounds v The Queen (2006) 228 ALR 190 at 197 [26], 211 [94]; ([2006] HCA 39).

31 The Queen $v$ Fellows and Arnold [1997] 2 All ER 548; The Queen v Oliver [2003] 1 Cr App R 28 at 466-467 [10]; cf Lawrence $v$ Texas 539 US 558 at 590 (2003).

32 See Macintosh (2005: 135-36), describing the resolution of the General Assembly of the United Nations of 8 March 2005. This approved a Declaration, proposed by the Sixth Committee, to 'prohibit all forms of human cloning inasmuch as they are incompatible with human dignity and the protection of human life'. The General Assembly vote was 84 to 34 in favour with 37 abstentions. 
purposes might accept the need to prohibit, or restrict, some biotechnological experiments. Hybridisation and xeno-transplantation of tissue across species clearly require, at the very least, restrictions and safeguards so as to prevent cross-species transmission of endogenous viruses. To do nothing is effectively to decide that nothing should be done. It does not necessarily amount to a decision to 'wait and see'.

This is why the regulation of technology is such an important subject. It is not one that can be ignored, simply because the subject matter, and the available regulatory techniques, are difficult and controversial.

3. Recognise the limited power to regulate: A third lesson, derived from the first two, is that the normal institutions of legal regulation often appear powerless in the face of new technology. This is clear in the case of attempts to regulate new information technology. So far as the Internet is concerned, the regulatory values of the United States inevitably exert the greatest influence on the way the Internet operates and what it may include. This means that both First Amendment and copyright protection values, established by the laws of the United States, profoundly influence the Internet's present design and operation. An attempt by another nation's laws (such as those of France) to prohibit transnational publication that is offensive to that country's values (such as advertising Nazi memorabilia) may face difficulties of acceptance and enforcement in the Internet. ${ }^{33}$

The same is true of biotechnology. The Australian Parliament initially enacted the Prohibition of Human Cloning Act 2002 (Cth) and the Research Involving Human Embryos Act 2002 (Cth). These were part of a package of laws aimed at the consistent prohibition in Australia of human cloning and other practices deemed unacceptable at the time. Both Acts were adopted on the basis of the promise of an independent review two years after the enactment. Such a review was duly established. It was chaired by a retired federal judge, the Hon John Lockhart. The review presented its report on December 2005. It recommended an end to the strict prohibitions of the 2002 legislation; the redefinition for legal purposes of the 'human embryo'; and the introduction of a system of licensing for the creation of embryos for use for therapeutic purposes (Australian Government, 2005).

Initially, the Australian Government rejected the recommendations of the Lockhart review. However, following strong political, scientific and media reaction, a conscience vote on an amending Act, introduced by a 
previous health minister, was allowed. In the outcome, the amendments were enacted. But, they were passed by the Australian Senate with only a tiny majority. ${ }^{34}$

The main argument that secured this outcome in Australia was the recognition of the pluralistic nature of the society; widespread reports on the potential utility of the research and experimentation; and the expressed conviction that experimentation would proceed in overseas countries with results that, if they proved successful, would necessarily be adopted and utilised in Australia. ${ }^{35}$ Interestingly, both the then prime minister and the leader of the federal opposition (soon to be his successor) voted against the amending Act. ${ }^{36}$

The global debates on the regulation of experiments using embryonic stem cells have often been driven by countries that, to put it politely, are not at the cutting edge of the applicable technology. ${ }^{37}$ On the other hand, the United States, certainly during the administration of President George W Bush, also adopted a conservative position on these topics in United Nations forums. As happened in Australia, this was to change on the election and re-election of President Barack Obama.

4. Recognise differentiating technologies: So far as regulation of technologies is concerned, the TELOS conference established the need to differentiate technologies for the purpose of regulation. It is not a case of one response fits all. Self-evidently, some forms of technology are highly sensitive and urgently in need of regulation. Unless the proliferation of nuclear weapons is effectively regulated, the massive destructive power that such technology presents has the potential to render all other topics theoretical. Similarly, some aspects of the regulation of biotechnology are sensitive, including the use of embryonic stem cells and germline modification. For some, the sensitivity derives from deep religious or other beliefs concerning the starting point of human existence. For others, it arises out of fears of irreversible experiments that may go wrong.

Somewhat less sensitive is the regulation of information technology. Yet this technology too presents questions about values concerning which

\footnotetext{
34 In the Australian House of Representatives, the vote was 82:62; see Australia, House of Representatives (2006: 127). In the Senate the vote was 34:31; see Australia, Senate (2006: 48).

35 See, for example, Australian, (2006: 15); Finkel \& Cannold (2006: 9); Sydney Morning Herald (SMH) (2006: 11); Carr (2006: 13).

36 Mr Howard spoke at the House of Representatives on 6 December 2006, (Australia, 2006: p 117); Mr Rudd also spoke to the House (Australia, 2006: 119).

37 Thus, Honduras was the national sponsor of the United Nations ban on human cloning, reproductive and therapeutic. See Macintosh (2005: 134).
} 
people may have strong differences of opinion. To outsiders, Americans seem to imbibe First Amendment values with their mother's milk. Lawyers from the United States sometimes have to be reminded that their balance between free speech and other human rights is viewed by most of the world as extreme and disproportionate.

5. Recognise different cultures: Most of the participants in the TELOS conference came from the developed world. They therefore reflected general attitudes of optimism and confidence about the outcome of rational dialogue and the capacity of human beings ultimately to arrive at reasonable responses to regulating technologies, on the basis of calm debate.

This is not, however, universally true. The conference in London coincided with a declaration by the Roman Catholic Bishop of Birmingham, the Most Rev Vincent Nichols, that Britain was facing a period of secular revulsion. This response was attributed to impatience with the instances of violence attributed to those with religious beliefs and the apparent obsession of some Christian churches with issues of sexuality and gender.

There is no doubt that the current age bears witness to many instances of religious fundamentalism. Modern secular democracies can usually prepare their regulations of technology without undue attention to such extremist considerations. But when the considerations come before international institutions, they may have to run the gauntlet of fundamental beliefs. Such religious beliefs are by no means confined to Islam. They also exist in Christianity, Judaism, Hinduism and other world religions. Because, in such instances, religious instruction is attributed to God and derived from human understandings of inerrant religious texts, it may brook no compromise and even no debate.

Recognising the coincidence of galloping technology and the force of religious fundamentalism is necessary to an understanding of what can be done in different countries to respond effectively to aspects of technology that challenge orthodox religious beliefs. In the Australian parliamentary debates on the amendment of the 2002 moratorium on human cloning and use of embryonic tissue, many of the legislators addressed the extent to which it was legitimate, in a pluralistic society, to allow beliefs, even of a majority, to control the design of national legal regulation. Yet, if such beliefs are treated as irrelevant, what other foundations can be provided for a coherent system of moral principle? In some societies such issues simply do not arise. The Taliban in Afghanistan would not entertain an open debate on topics that are 
treated as concluded by a holy text. The diversity of regulatory responses to new technology, therefore, grows out of the different starting points in each society.

6. Basing regulation on good science: In the early days of the HIV pandemic, I served on the Global Commission on AIDS of the World Health Organisation. One of the members, June Osborn, then a professor of public health in the University of Michigan, taught the importance of basing all regulatory responses to the epidemic upon good science. The danger of responses based on assumptions, religious dogmas, intuitive beliefs, or popular opinion were that they would not address the target of regulation effectively.

The intervening decades have suggested that the countries that have been most successful in responding to HIV/AIDS have been those that have observed Osborn's dictum (Plummer \& Irwin, 2006: 1). The same is true of the subjects of biotechnology, information technology and neuroscience examined in the TELOS conference. All too often, science and technology shatter earlier assumptions and intuitions.

For example, the long-held judicial assumption that jurors, and judges themselves, may safely rest conclusions concerning the truth of witness testimony on the basis of the appearance of witnesses and courtroom demeanour has gradually evaporated because scientific experiments shatter this illusion. ${ }^{38}$ One day, by subjecting witnesses to brain scans, it may be possible to demonstrate objectively the truthfulness or falsity of their evidence. One lesson of the Illes paper for the TELOS conference is that we have not yet reached that position. If, and when, it arrives, other issues will doubtless be presented for regulators. We are not there yet. But any regulation must recognise the need to remain abreast of scientific knowledge and technological advances.

7. Addressing the democratic deficit: This brings me to the last, and most pervasive, of the lessons of the TELOS conference. Technology races ahead. Often its innovations quickly become out of date. Laws addressed to a particular technology are overtaken and rendered irrelevant or even obstructive. Nowadays, scientific knowledge, technological inventions and community values change radically in a very short space of time.

Within less than two years of the initial laws, demands were made for reversal to the Australian federal prohibition on therapeutic cloning. Within five years, the prohibition was repealed. In such an environment, there is an obvious danger for the rule of law. It is impossible to expect

38 See, for example, Fox v Percy (2003) 214 CLR 118 at 129 [31]; ([2003] HCA 22). 
of legislatures, with their many responsibilities, that they will address all of the technological developments necessary or useful for regulatory purposes. The average legislator often finds such issues complex and impenetrable. They are rarely political vote-winners. They struggle to find a place in the entertainment and personality politics of the present age as well as with the many other competing questions awaiting political decision-making. This leaves a gap in democratic decisionmaking in this sphere of regulation. It is a gap that is being filled, in part, by 'Code', which incorporates regulations designed by inventors of information systems themselves in the structure of such systems but without a democratic input or the necessity of human moral judgment.

The democratic deficit presented by contemporary technology is thus the largest potential lesson from the TELOS conference. In an age when technology is so important to society, yet so complex and fast moving that it often defies lay understanding, how do we adapt our accountable lawmaking institutions to keep pace with such changes? One means, undertaken in Australia, is by the use of consultative mechanisms such as the ALRC (Chalmers, 2005: 374) ${ }^{39}$ or independent inquiries, such as the Lockhart committee (Cooper, 2006: 27; Stobbs, 2006, 247; Karpin, 2006: 599). In such cases, the very process of consultation and public debate promotes a broad community understanding of the issues, an appreciation of different viewpoints and an acceptance of any regulations adopted, even when they may give effect to conclusions different from one's own.

Adapting the legislative timetable and machinery to the challenges of modern governance is a subject that has engaged law reform bodies and executive government for decades. In Australia, proposals for some form of delegated legislation have been made to increase the implementation of such reports. Often they lie unconsidered for years, or indefinitely, not because of any real objections to their proposals but because of the legislative logjam (Mason, 1971: 197). In the United Kingdom, suggestions for a fast-track system for implementing reports of the law commissions have been under review for some time. ${ }^{40}$

In the face of radically changing technologies and the danger of a growing democratic deficit, it will obviously be necessary to adapt and supplement the lawmaking processes we have hitherto followed in most countries. Various forms of delegated legislation may need to

39 Important recent reports of the ALRC in the field have included Essentially yours: the regulation of human genetic information in Australia (2003).

40 See Kirby (2006: 466). Such a fast track mechanism was adopted in the United Kingdom in 2009. 
be considered. So may the enactment of over-arching laws, expressed in general terms, which will not be quickly reduced to irrelevancy by further technological change. ${ }^{41}$ Addressing the weaknesses in democratic accountability of large and complex modern government is an important challenge to legal and political theory. ${ }^{42}$ The TELOS conference demonstrated once again the ingredients and urgency of the problem. It will take more conferences, and more books like this, to provide the solutions appropriate to the differing systems of government operating in different countries.

\section{The future}

Consideration of these remarks will demonstrate, even to the most sceptical, the variety of the issues raised at the TELOS conference, the importance of the topics considered and the danger of doing nothing to envisage, and carry forward, the efficient regulation of technology where that course is judged beneficial and necessary.

TELOS will doubtless go on to establish a network amongst those lawyers and others who are interested in the developments of technology of special relevance to the law and concerned about the potential democratic deficit identified during the deliberations.

Future conferences will need to broaden the scope of the technologies addressed, so that they include participants with expertise in nuclear technology, the technologies of energy and global climate change and of explorations of the biosphere and outer space. They will need to widen the participation from other parts of the world, including Russia and India, both countries of significance because of their technological capacity. Participants from poorer countries will be essential so as to reflect the diversity of humanity.

There will also be a need to deepen the examination of the law so as to include case studies of effective, as well as ineffective attempts to regulate technology by municipal law in addition to those attempts that are now emerging from international agencies designed to address global technology on a trans-border basis. Finally, it will be necessary to extend the fields of expertise of participants. The involvement of political philosophers, of persons who sometimes advocate more vigorous regulation, of civil society organisations, law reformers, politicians and legislative drafters would enlarge the pool of expertise in essential fields.

41 Issues considered in R v Quintaralle (on behalf of Reproductive Ethics) v Human Fertilisation and Embryology Authority [2005] UKHL 28 at [25]; compare with Brownsword, (nd: 20).

42 ibid. 
The TELOS conference demonstrated that regulating technologies is not a matter appropriate to purely verbal analysis of the traditional legal kind. We cannot find the way ahead by simply reading the judicial reasoning of our predecessors, however learned they may have been. In default of more effective solutions, the common law system authorises judges to fill the gaps left by lawmakers. ${ }^{43}$ Sometimes this is necessary. But a more coherent solution is desirable. TELOS has opened a dialogue as to how that solution may be offered.

A great judge, and one of my predecessors in the High Court of Australia, Justice Windeyer, once declared of the relationship between law and medical technology, that the law generally marches in the rear and limping a little. ${ }^{44}$ Windeyer was a soldier as well as a judge. He knew what he was talking about when he used this metaphor. In the years since he offered his description the gap that he discerned has widened. The institutional problem has deepened. That is why TELOS is so important. It is why the subject matters here examined concern nothing less than the future of law itself.

\section{References}

Acheson, D, 1969, Present at the creation: my years at the state department, WW Norton, Inc, 1969.

Andorno, R, 2004, 'The precautionary principle: a new legal standard for a technological age', Journal of International Biotechnology Law, vol 1, pp 1119.

- 2007, 'Global bioethics at UNESCO: in defence of the Universal declaration on bioethics and human rights', Journal of Medical Ethics, vol 33, pp 150-54.

Australia, House of Representatives, 2006, Debates, 6 December.

Australia, Senate, 2006, Debates, 7 November.

Australian, 2006, 'Let the debate begin: Australia should lead, not lag, in regenerative medicine', Australian, 7 August, p 15.

Australian Government, 2005, Legislation review: Prohibition of Human Cloning Act 2002 and the Research Involving Human Embryos Act 2002. Reports, Canberra.

\footnotetext{
43 Recent illustrations include judicial decisions in cases of 'wrongful birth' and 'wrongful life'. See eg Cattanach v Melchoir (2003) 215 CLR 1; ([2003] HCA 38) and Harriton v Stevens (2006) 226 CLR 52; [(2006)] HCA 15); cf McKay v Essex Area Health Authority [1983] QB 1166; Gleitman v Gosgrove 227 Atl Rep (2d) 689 (1967) and Curlender v Bio-Science Laboratories 165 Cal Rptr 477 (1960).

44 Mount Isa Mines Ltd v Pusey (1970) 125 CLR 383 at 395.
} 
Professionalism in the Information and Communication Technology Industry

Australian Law Reform Commission (ALRC), 1977, Human tissue transplants, report no 7, 1977.

- 1979 (a), Unfair publication: defamation and privacy, report no 11, Australian Government Publishing Service, Canberra.

- 2003, Essentially yours: the regulation of human genetic information in Australia, report no 96.

- 1979 (b), Privacy and the Census, report no 12, Australian Government Publishing Service, Canberra.

- 1983, Privacy, report no 22, Australian Government Publishing Service, Canberra.

Brennan, D, 2006, 'What can it mean "to prevent or inhibit the infringement of copyright"?: - a critique of Stevens v Sony', Australian Intellectual Property Journal, vol 17, pp 81-98.

Brownsword, R, nd, 'Interpretive re-connection, the reproductive revolution and the rule of law', unpublished, $20 \mathrm{pp}$

Carr, B, 2006, 'Age-old objections must not be allowed to delay this revolution', Sydney Morning Herald, 25 July, p 13.

Chalmers, D, 2005, 'Science, medicine and health in the work of the Australian Law Reform Commission', in D Weisbrot \& B Opeskin (eds), The promise of law reform, Federation Press, pp 374-87.

Cooper, D, 2006, 'The Lockhart review: where now for Australia?', Journal of Law and Medicine, vol 14, pp 27-44.

de Zwart, M, 2007, 'Technological enclosure of copyright: the end of fair dealing?', Australian Intellectual Property Journal, vol 18, pp 7-38.

Finkel, B \& Cannold, L, 2006, 'Day for stem cells and the hope of finding cures', Sydney Morning Herald, 7 August, p 9.

Fitzgerald, B, 2005, 'The PlayStation mod chip: a technological guarantee of the digital consumer's liberty or copyright menace/circumvention device?', Media and Arts Law Review, vol 10, pp 85-98.

Karpin, I, 2006, 'The uncanny embryos: legal limits to human reproduction without women', Sydney Law Review, vol 28, pp 599-623.

Kirby, MD, 2001, 'Intellectual property and the human genome', Australian Intellectual Property Journal, vol 12, pp 61-81. 
- 2006, 'Law reform and human rights — Scarman's great legacy', Legal Studies, vol 26, 2006, pp 449-74.

Macintosh, KL, 2005, 'Human clones and international human rights', University of Technology, Sydney Review, vol 7, pp 134-56.

Martinez, J, 2003, 'Towards an international judicial system', Stanford Law Review, vol 56, pp 429-529.

Mason, AF, 1971, 'Law reform in Australia', Federal Law Review, vol 4, p 197.

Murphy, T (ed), 2009, New technologies and human rights, OUP.

National Commission for the Protection of Human Subjects of Biomedical and Behavioural Research, 1975, Report and recommendations: research on the fetus, US Department of Health, Education and Welfare, Bethesda, Maryland.

New Zealand. Royal Commission on Contraception, Sterilisation and Abortion, 1977, Contraception, sterilisation and abortion in New Zealand, Government Printer, Wellington.

Organisation for Economic Cooperation and Development, 1980, Guidelines on the protection of privacy and transborder data flows, Paris.

Peel, J, 1972, Code of practice on the use of foetuses and foetal material for research, HMSO, London.

Plummer, D \& Irwin, L, 2006, 'Grassroots activities, national initiatives and HIV prevention: clues to explain Australia's dramatic early success in controlling the HIV epidemic', International Journal of STD and AIDS, vol 17, pp 78793.

Robertson, JA, 2001, 'Why human reproductive cloning should not in all cases be prohibited', Legislation and Public Policy, vol 4, pp 35-43.

Shikai, YM, 2002, 'Don't be swept away by mass hysteria: the benefits of human reproductive cloning and its future', Southwestern University Law Review, vol 33, pp 259-84.

Stobbs, N, 2006, 'Lockhart review into human cloning and research involving human embryo - closing the gap', Queensland Lawyer, vol 26, pp 247-51.

Sydney Morning Herald (SMH), 2006, 'A greater moralilty at stake on the decision of stem-cells research', SMH, 14 August, p 11.

Woodruff, MFA, 1968, The transplantation of tissues and organs, Chas Thomas, Illinois. 